\title{
UPAYA PEMBINAAN MASYARAKAT DALAM RANGKA PENGEMBANGAN DESA EKOWISATA DI DUSUN MENDIRO, DESA PANGLUNGAN, KECAMATAN WONOSALAM, KABUPATEN JOMBANG
}

\author{
I Dewa Gde Satrya, Thomas Stefanus Kaihatu, Lexi Pranata \\ Fakultas Pariwisata, Universitas Ciputra Surabaya \\ dewa.gde@ciputra.ac.id
}

\begin{abstract}
Abstarct. The problems faced by the Mendiro village community are the function of protected forests, hunting of birds, timber theft / bamboo shoots, river pollution, logging in springs and the transfer of land ownership owned by people outside Wonosalam. The purpose of community service is to provide knowledge and skills to the hamlet of Mendiro Village and Panglungan Village to create a village of residence to become an ecotourism village. Over time, found collaboration of agro-tourism products which is the development of the potential that exists in the field. Service is carried out using participatory counseling methods followed by demonstrations and practices. The training activities are carried out intensively from February to August 2018 at the Panglungan Village Hall and at the residents' houses which are used as Tourist Information Centers. The activity begins with the provision of materials on the principles of ecotourism and community-based tourism, and is continued with comprehensive material to create an ecotourism village, starting with the provision of local culinary delights to making homestays. The conclusion of this dedication activity shows that the residents have high motivation to make their home village become an ecotourism village in order to overcome a number of problems listed above.
\end{abstract}

Keywords: ecotourism, agro-tourism, community-based tourism

\begin{abstract}
Abstrak. Masalah yang dihadapi masyarakat Desa Mendiro adalah fungsi hutan lindung, perburuan burung satwa, pencurian kayu/rebung, pencemaran sungai, penebangan di area mata air dan alih kepemilikan lahan milik orang di luar Wonosalam. Tujuan pengabdian kepada masyarakat adalah untuk memberi pengetahuan dan keterampilan kepada masyarakat Dusun Mendiro dan Desa Panglungan untuk menciptakan desa tempat tinggal menjadi desa ekowisata. Pengabdian dilakukan dengan menggunakan metode penyuluhan partisipatif yang diikuti dengan demonstrasi dan praktik. Kegiatan pelatihan dilaksanakan secara intensif sejak bulan Februari sampai Agustus 2018 bertempat di Balai Desa Panglungan dan di rumah warga yang dijadikan Tourist Information Centre. Kegiatan diawali dengan pemberian materi tentang prinsip-prinsip ekowisata dan pariwisata berbasis masyarakat, dan dilanjutkan dengan materi yang komprehensif untuk menciptakan desa ekowisata, mulai penyediaan kuliner lokal hingga pembuatan homestay. Kesimpulan dari kegiatan pengabdian ini menunjukkan bahwa para warga memiliki motivasi yang tinggi untuk menjadikan desa tempat tinggal mereka menjadi desa ekowisata guna mengatasi sejumlah permasalahan yang tertera di atas.
\end{abstract}

Kata kunci: Ekowisata, Pariwisata Berbasis Masyarakat

\section{PENDAHULUAN}

Pada tahun pertama program pengabdian masyarakat diadakan di Wonosalam, pertumbuhan terjadi di beberapa sisi. Khususnya, dari segi kesadaran masyarakat untuk berbenah menjadi desa wisata. Kini, di tahun kedua, desa ekowisata Wonosalam dijalankan dengan dukungan yang lebih massif dari pemerintah desa setempat.

Dukungan aparatur Desa Panglungan, Kecamatan Wonosalam, untuk menciptakan desa wisata semakin nyata melalui pembangunan wahana wisata di tanah kas desa. Pembangunan wahana wisata yang tidak masuk di area yang diintevensi oleh program Pengembangan Desa
Mitra, melainkan bersebalahan, dapat dimaknai sebagai upaya kolaborasi antara Universitas Ciputra melalui skim PPDM dengan Desa Panglungan. Dengan demikian, dampak dari program PPDM untuk mendorong pembangunan di desa tampak nyata.

Tantangan dari pembangunan desa ekowisata di Wonosalam sebagai berikut, pertama, perlunya kebijakan dari Pemerintah Desa yang mendukung percepatan pembangunan infrastruktur untuk memperbaiki akses menuju Dusun Mendiro, Desa Panglungan, yang menjadi pusat program menciptakan desa ekowisata. Pembangunan infrastruktur sebenarnya telah dilakukan oleh Pemerintah Desa di beberapa ruas jalan yang menghubungkan jalan utama di 
Kecamatan menuju Dusun Mendiro yang terletak di area dataran tinggi. Namun, belum semua jalan dan akses menuju Dusun Mendiro telah diperbaiki. Hal ini diharapkan dapat terus dijalankan oleh Pemerintah Desa.

Kedua, selama dua tahun berjalannya program PPDM, di mana tahun pertama bernama skim IbDM, keterlibatan masyarakat dalam program yang dibutuhkan pula untuk regenerasi pengurus dan pelaku wisata, masih didominasi generasi tua. Hal ini tak dapat dielakkan, karena tokoh kunci pelestari hutan dan konservasi di sana adalah generasi tua. Namun, tantangan ini telah diatasi dengan pembentukan Kelompok Sadar Wisata (Pokdarwis), juga pengurus Bumdes bentukan Pemerintah Desa, yang melibatkan segenap unsur masyarakat, mulai Karang Taruna yang merepresentasikan generasi muda, kelompok ibu dan perempuan, serta kelompok sesepuh yang selama ini menjadi tokoh kunci di masyarakat.

Ketiga, pengembangan desa ekowisata meniscayakan keseimbangan antara aktivitas wisata dengan konsep pelestarian alam dan budaya lokal. Maknanya, pembatasan jumlah kunjungan wisatawan menjadi keniscayaan. Hal ini belum banyak dipahami oleh pihak masyarakat yang menjadi mitra, karena beranggapan dampak pembangunan wisata kurang terlihat dari segi kunjungan wisatawan.

Dalam hal ini, kuantitas wisatawan menjadi prioritas setelah kualitas wisatawan. Artinya, dengan adanya penataan daerah wisata yang berbasiskan pada ekowisata, kualitas wisatawan menjadi penting. Yang terkait dengan kualitas wisatawan adalah, latar belakang pengunjung, motivasi melakukan perjalanan wisata, dan tentu saja manfaat ekonomi dari adanya perjalanan wisata tersebut. Dengan kata lain, meskipun ada pembatasan dalam jumlah Tabel 1 Matriks Permasalahan Pokok yang Dihadapi Kelompok Pelindung Hutan di Dusun Mendiro, Desa Panglungan, Kecamatan Wonosalam

\begin{tabular}{|c|c|c|c|}
\hline No & Masalah & Solusi Transfer IPTEK & Luaran \\
\hline 1 & $\begin{array}{l}\text { Alih fungsi Hutan } \\
\text { Lindung }\end{array}$ & $\begin{array}{c}\text { Pelatihan konservasi dan pengemasan } \\
\text { produk ekowisata "Jelajah Hutan dan } \\
\text { Taman Keanekaragaman Hayati" } \\
\text { Kelompok Pelestari Hutan (KEPUH) } \\
\text { Wonosalam }\end{array}$ & $\begin{array}{l}\text { 1. } \begin{array}{l}\text { Terpeliharanya puluhan jenis pohon } \\
\text { hutan }\end{array} \\
\text { 2. Produk Ekowisata dan Scientific } \\
\text { Tourism "Jelajah Hutan dan Taman } \\
\text { KEHATI" }\end{array}$ \\
\hline 2 & $\begin{array}{l}\text { Perburuan Burung } \\
\text { Satwa }\end{array}$ & $\begin{array}{l}\text { Pelatihan konservasi dan pengemasan } \\
\text { produk ekowisata "bird watching" }\end{array}$ & 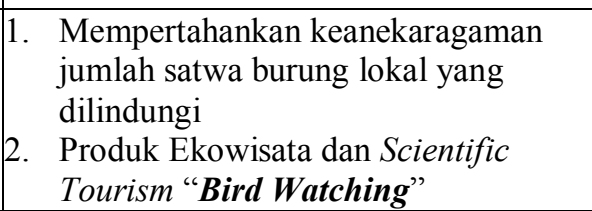 \\
\hline 3 & $\begin{array}{l}\text { Pencurian } \\
\text { Kayu/Rebung }\end{array}$ & $\begin{array}{c}\text { Pelatihan konservasi dan pengemasan } \\
\text { produk ekowisata "Jelajah Hutan dan } \\
\text { Taman Keanekaragaman Hayati" } \\
\text { KEPUH Wonosalam }\end{array}$ & $\begin{array}{l}\text { 1. Terpeliharanya puluhan jenis pohon } \\
\text { hutan } \\
\text { 2. Produk Ekowisata dan Experiential } \\
\text { Tourism "Jelajah Hutan" }\end{array}$ \\
\hline
\end{tabular}

kunjungan wisatawan, namun karena keterlibatan mereka dalam kunjungan wisata yang berbasiskan pada ekowisata merasa berkesan, tak menutup kemungkinan adanya manfaat ekonomi yang juga tidak sedikit.

Sebagai contoh, keterlibatan dunia usaha dalam program CSR penanaman pohon di area Hutan Lindung di Dusun Mendiro, menjadi bukti banyaknya dukungan dan keterlibatan dunia usaha dalam pembangunan destinasi ekowisata yang mengedepankan kelestarian alam. Selain itu, beragamnya latar belakang profesi wisatawan yang notabene berasal dari kelompok well educated, berkebangsaan asing, menjadi signal bahwa ekowisata seharusnya memiliki positioning di tempat yang terhormat.

Pada akhirnya, pelaksanaan PPDM yang direncanakan sesuai dengan yang tertera di rencana kegiatan dalam proposal tahun kedua, diarahkan untuk mencapai tujuan berikut ini, pertama, menyelamatkan mata air di Wonosalam dengan cara meningkatkan pendapatan masyarakat melalui kegiatan wisata berbasis ekowisata. Kedua, membantu program pemerintah dalam pembangunan masyarakat di wilayah desa. Ketiga, membantu mensukseskan terlaksananya program RPJM Desa. Keempat, meningkatkan kemandirian dan kesejahteraan masyarakat desa. Dan, kelima, mempercepat pembangunan desa pada berbagai bidang secara berkelanjutan.

Berdasarkan hasil identifikasi masalah yang dilakukan bersama-sama dengan tokoh kunci di masyarakat Mendiro dan mitra diperoleh beberapa kesimpulan masalah utama yang paling mendesak untuk diselesaikan bersama. Permasalahan utama dan justifikasinya diperlihatkan pada tabel 1 berikut ini. 


\begin{tabular}{|c|c|c|c|}
\hline 4 & Pencemaran Sungai & $\begin{array}{l}\text { Pelatihan konservasi dan pengemasan } \\
\text { produk ekowisata "eksplorasi sungai" }\end{array}$ & \begin{tabular}{|l} 
1. Lestarinya makroinvertebrata sungai \\
dan ikan hulu \\
2. Produk Ekowisata dan Experiential \\
Tourism "Eksplorasi Sungai"
\end{tabular} \\
\hline 5 & $\begin{array}{l}\text { Penebangan di Area } \\
\text { Mata Air }\end{array}$ & $\begin{array}{c}\text { Pelatihan Konservasi Kelompok } \\
\text { Pelestari Mata Air dan pengemasan } \\
\text { produk ekowisata "Experiential } \\
\text { Tourism Mata Air" }\end{array}$ & $\begin{array}{l}\text { 1. Terpeliharanya puluhan mata air } \\
\text { 2. Produk Ekowisata dan Experiential } \\
\text { Tourism "Eksplorasi Mata Air" }\end{array}$ \\
\hline 6 & $\begin{array}{l}50 \% \text { lahan milik } \\
\text { orang luar } \\
\text { Wonosalam }\end{array}$ & $\begin{array}{c}\text { Penguatan kelembagaan Pariwisata } \\
\text { berbasis Masyarakat }\end{array}$ & Model pariwisata berbasis masyarakat \\
\hline
\end{tabular}

Berdasarkan uraian permasalahan yang dihadapi oleh masyarakat setempat diketahui bahwa cara untuk mengatasi enam masalah pokok di atas melalui pelatihan dan penyuluhan secara intensif untuk mengemas Desa Panglungan menjadi desa ekowisata.

Target luaran yang diharapkan dari pelaksanaan kegiatan PPDM sebagai berikut.

(a) Target luaran jangka pendek

Target luaran jangka pendek yang diharapkan setelah kegiatan PPDMM ini adalah:

- mitra dapat menerapkan manajemen pariwisata berbasis ekowisata

- mitra dapat mengetahui cara pengelolaan pariwisata berbasis masyarakat

- peningkatan pendapatan melalui kunjungan wisatawan ekowisata yang meningkat dari segi kualitas wisatawan maupun jumlah kunjungan.

(b) Target luaran jangka panjang

Target luaran jangka panjang yang diharapkan ialah terbentuknya wiraswasta baru dari UKM yang intens dan mau memproduksi susu kambing pasteurisasi dalam kemasan gelas dengan label Susu Beke (Suke).

\section{METODE PELAKSANAAN}

Kegiatan yang dilakukan dalam pengabdian kepada masyarakat adalah upaya mengatasi permasalahan pokok mitra, yaitu melalui peningkatan pengetahuan dan kemampuan teknis pariwisata berbasis masyarakat dengan produk utama ekowisata. Transfer iptek untuk meningkatkan kemampuan teknis mitra dilakukan melalui pendekatan praktik belajar dan berbuat (learning by doing), yaitu melalui pelatihan terpadu dan praktik yang bersifat partisipatif di bawah supervisi dan diikuti dengan pendampingan oleh pelaksana kegiatan.

\section{Metode Pendekatan}

Metode pendekatan yang ditawarkan untuk mendukung realisasi program dijelaskan sebagai berikut.

\section{a. Metode Penyuluhan Partisipatif}

Kegiatan pembelajaran tentang manajemen pariwisata berbasis masyarakat dan prinsip pengelolaan ekowisata melalui metode penyuluhan partisipatif dengan cara pertemuan rutin yang diisi ceramah dan diskusi di tingkat Kelompok Peduli Hutan, Kelompok Sadar Wisata, maupun Bumdes yang dibentuk oleh aparatur Desa.

\section{b. Metode Focus Group Disscussion (FGD) \\ Metode Focus Group Disscussion} (FGD) adalah melakukan dialog aktif dalam kelompok-kelompok kecil antara masyarakat dengan fasilitator untuk menginvestigasi permasalahan lokal yang berkaitan dengan pengelolaan pariwisata berbasis masyarakat dengan produk utama ekowisata dalam bentuk Jelajah Hutan Lindung, Jelajah Sungai, Jelajah Mata Air, Bird Watching, dan Jelajah Desa.

\section{c. Metode Pelatihan (Demonstrasi dan Kegiatan Praktik oleh Peserta)}

Kegiatan pelatihan meliputi kegiatan demonstrasi dan kegiatan praktik oleh anggota kelompok pelindung hutan, karang taruna, siswa sekolah di Desa Panglungan, komunitas ibu dan penggerak PKK, serta tim khusus marketing dan public relation dari kalangan warga. Pada kegiatan demonstrasi, tim pelaksana akan mengundang tim dosen Universitas Ciputra yang memiliki beberapa kepakaran untuk berbagi pengalaman dan pengetahuan, misalnya cara memberikan service kepada wisatawan, pelayanan dalam bentuk tour guide, pelatihan bahasa Inggris, serta pemantapan nilai-nilai Sadar Wisata.. Dalam kegiatan praktik ini, petani mula-mula diberi contoh.

\section{d. Metode Pembimbingan dan Pendampingan Peserta oleh Tim Pelaksana \\ Kegiatan ini dilakukan dengan pendekatan kelembagaan, yaitu proses pembimbingan dan pendampingan yang terus-}


menerus melalui pembentukan Kelompok Sadar Wisata (Pokdarwis) Desa Panglungan, yang pembentukannya telah difasilitasi oleh tim pelaksana dan diresmikan melalui Surat Keputusan Kepala Desa Panglungan. Pelaksanaan pendampingan ini difokuskan pada penerapan pariwisata berbasis masyarakat dan pengemasan desa ekowisata dengan variasi produk wisata yang telah dirumuskan berdasarkan keunggulan yang dimiliki Dusun Mendiro, Desa Panglungan, Kecamatan Wonosalam. Matriks pada gambar 1 di bawah menunjukkan permasalahan dan proses pemecahannya.

\section{Tahapan Pelaksanaan Kegiatan}

a. Tahap Persiapan Awal dengan Based Line Survey

Survey pendahuluan dilakukan dengan cara mengadakan perkuliahan lapangan di Dusun Mendiro, Desa Panglungan, Kecamatan Wonosalam. Melalui survey ini, diketahui permasalahan dan potensi yang ada, sekaligus memperlihatkan opportunity untuk kegiatan pengabdian masyarakat.

\section{b. Tahap Penggalangan Grup Target (Kelompok Sasaran)}

Tahapan ini untuk mengkonkretkan rumusan permasalahan, potensi lokal dan peluang kegiatan pengabdian masyarakat untuk turut berkontribusi memecahkan masalah di masyarakat. Selain itu, tahapan ini untuk memetakan orang-orang kunci yang menjadi mitra program pengabdian masyarakat.

\section{c. Tahap Persiapan Penyediaan Materi}

Tahap kegiatan ini meliputi persiapan materimateri yang akan diberikan dan penyediaan sarana pendukung dalam kegiatan penyuluhan, di antaranya prinsip-prinsip dasar ekowisata, penerapan Sapta Pesona Wisata, penanaman nilai Sadar Wisata, kaedah tentang service excellent, tour guiding dan english for tourism.

\section{d. Kegiatan Penyuluhan}

Kegiatan ini dilakukan untuk memberi penyuluhan mengenai materi-materi sebagai berikut:

- Penyuluhan peningkatan hospitality

- Penyuluhan penyusunan Standard Operating Procedure

- Penyuluhan penyusunan standar keamanan dan keselamatan (safety and security)

e. Tahap Pelatihan dalam Bentuk Demonstrasi dan Praktik Pengolahan Susu Kambing PE

- Pelatihan pengemasan paket wisata: penanda arah, bundling harga, area parkir, resepsionis dan reservasi, alur wisata, tourist information centre, laundry, $\mathrm{P} 3 \mathrm{~K}$.

- Pelatihan tour guiding

- Pelatihan penguatan atraksi wisata: mata air, agrowisata buah durian dan buah lainnya, eksplorasi desa wisata dan potensi lainnya.

- Pelatihan standardisasi local homestay dan MCK

- Pelatihan penyajian makanan dan minuman khas desa

- Perumusan destination branding dan icon attraction

\section{f. Tahap Pembimbingan}

Kegiatan ini bertujuan untuk membimbing pengelolaan desa ekowisata dan penerapan pariwisata berbasis masyarakat. Pembimbingan secara intensif di bagian marketing juga dilakukan kepada warga Panglungan yang ditugaskan khusus sebagai marketing dan public relation. Tugas mereka mengelola website visitwonosalam.com serta mengelola social media yang bertujuan untuk menciptakan viral dan story di Instagram, twitter, facebook serta youtube.

\section{g. Tahap Pendampingan}

Tahapan pendampingan dilakukan pada bidangbidang di bawah ini:

- Penyusunan struktur organisasi dan job description

- Pelatihan manajemen keuangan dan manajemen usaha

- Pembuatan sistem informasi wisata

- Pelatihan team work

- Program kemitraan

- Penguatan kelompok sadar wisata

\section{h. Tahap Evaluasi}

Evaluasi dilakukan secara rutin melalui rapat bersama Tim Pelaksana dengan Pokdarwis, serta koordinasi dengan Kepala Desa. Selama ini, evaluasi dilakukan tidak secara kaku, tetapi lebih kepada sharing informasi aktivitas yang dilakukan dalam pengelolaan desa ekowisata. Semisal, ketika menerima tamu dalam jumlah besar dari Sekolah Al Falah sebanyak 100 orang, maupun ketika menerima tamu khusus dari Amsterdam, Belanda, pasangan suami istri Huub dan Inge yang berprofesi sebagai specialist data information.

\section{HASIL DAN PEMBAHASAN}

Kegiatan pengabdian kepada masyarakat dilakukan di beberapa tempat di Desa Panglungan. Di antaranya, di Balai Desa Panglungan, di Taman Keanekaragaman Hayati, 
di Hutan Lindung Dusun Mendiro, dan di Tourist Pelindung Hutan.

Information Centre di rumah Ketua Kelompok

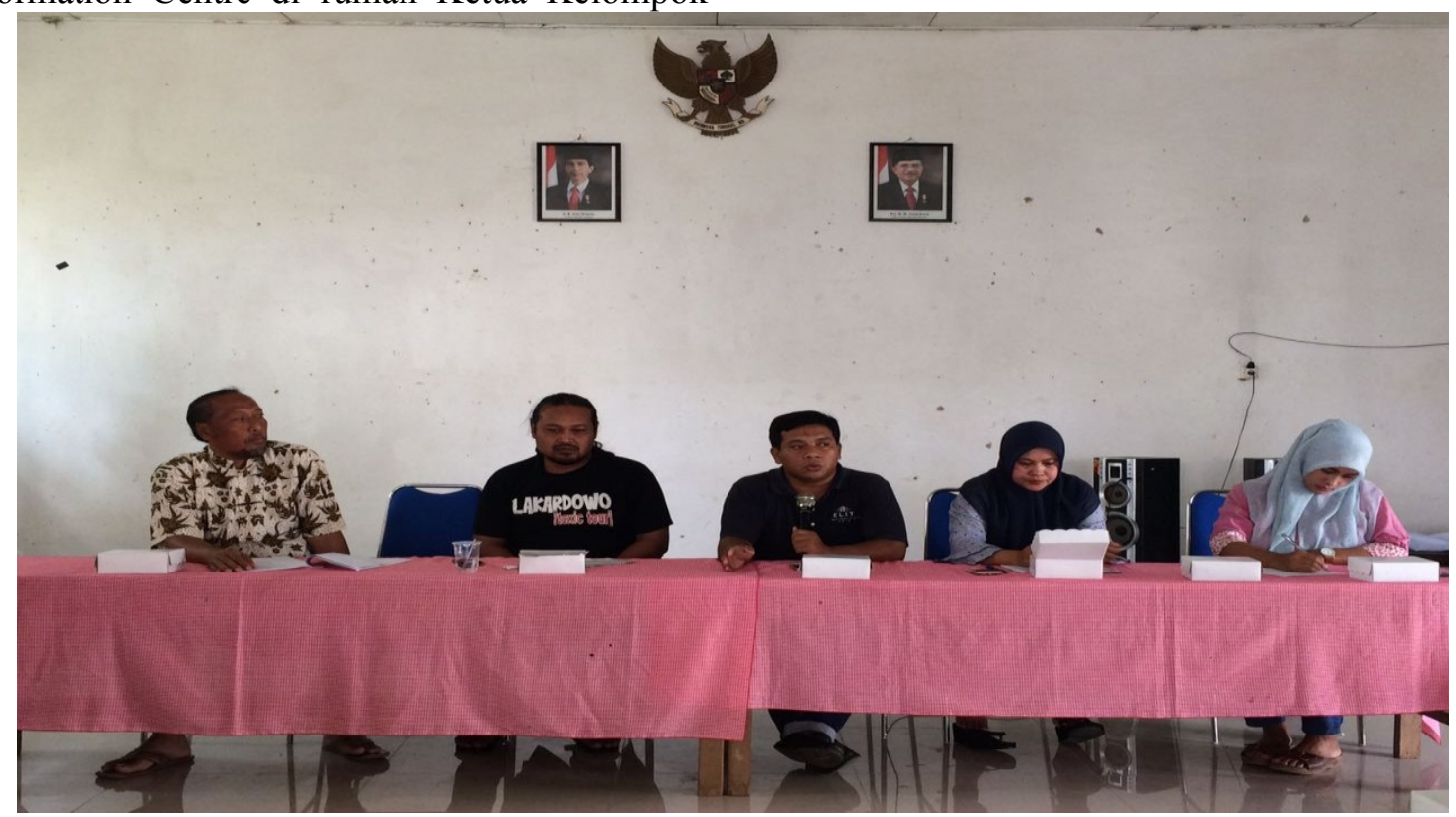

Gambar 1 Penyuluhan di Balai Desa Panglungan

Materi pelatihan yang diberikan kepada warga Desa Panglungan, diarahkan untuk memecahkan persoalan sekaligus menghasilkan luaran penciptaan desa ekowisata dengan beraneka produk khasnya. Hal ini dapat terlihat pada tabel di bawah ini.

Tabel 2. Hasil dan Luaran yang Dicapai

\begin{tabular}{|c|c|c|c|}
\hline No & Aspek & Hasil & Luaran \\
\hline 1 & Produk & $\begin{array}{ll}\text { Pengemasan paket wisata: } \\
\text { 1. } & \text { Penanda arah yang jelas } \\
\text { 2. } & \text { Bundling harga } \\
\text { 3. } & \text { Tersedia warung desa } \\
\text { 4. } & \text { Tersedia area parkir } \\
\text { 5. } & \text { Adanya alur wisata } \\
\text { 6. } & \text { Adanya Tourist Information } \\
\text { 7. } & \text { Centre } \\
\text { 7. } & \text { Tersedia P3K }\end{array}$ & \multirow[t]{4}{*}{$\begin{array}{l}\text { Produk Ekowisata, Scientific Tourism } \\
\text { dan Edu-Tourism: } \\
\text { 1. Jelajah Hutan } \\
\text { 2. Jelajah Mata Air } \\
\text { 3. Jelajah Sungai } \\
\text { 4. Bird Watching } \\
\text { 5. Jelajah Taman KEHATI } \\
\text { (Keanekaragaman Hayati) } \\
\text { 6. Jelajah Desa }\end{array}$} \\
\hline & & $\begin{array}{l}\text { Penguatan sumber daya manusia } \\
\text { 1. } \\
\text { 2our guide terlatih } \\
\text { Keramahan dan kesiapan pemilik } \\
\text { homestay } \\
\text { 3. } \\
\text { Makanan minuman khas desa } \\
\text { yang diproduksi warga }\end{array}$ & \\
\hline 2 & Pelayanan & $\begin{array}{l}\text { Wawasan dan pelaksanaan Sapta } \\
\text { Pesona Wisata di Dusun Mendiro, } \\
\text { Desa Pangklungan, Kecamatan } \\
\text { Wonosalam }\end{array}$ & \\
\hline 3 & Pengelolaan & $\begin{array}{l}\text { 1. Destination branding } \\
\text { 2. Dibentuk Pokdarwis Desa } \\
\text { Pangklungan, Kecamatan } \\
\text { Wonosalam }\end{array}$ & \\
\hline
\end{tabular}




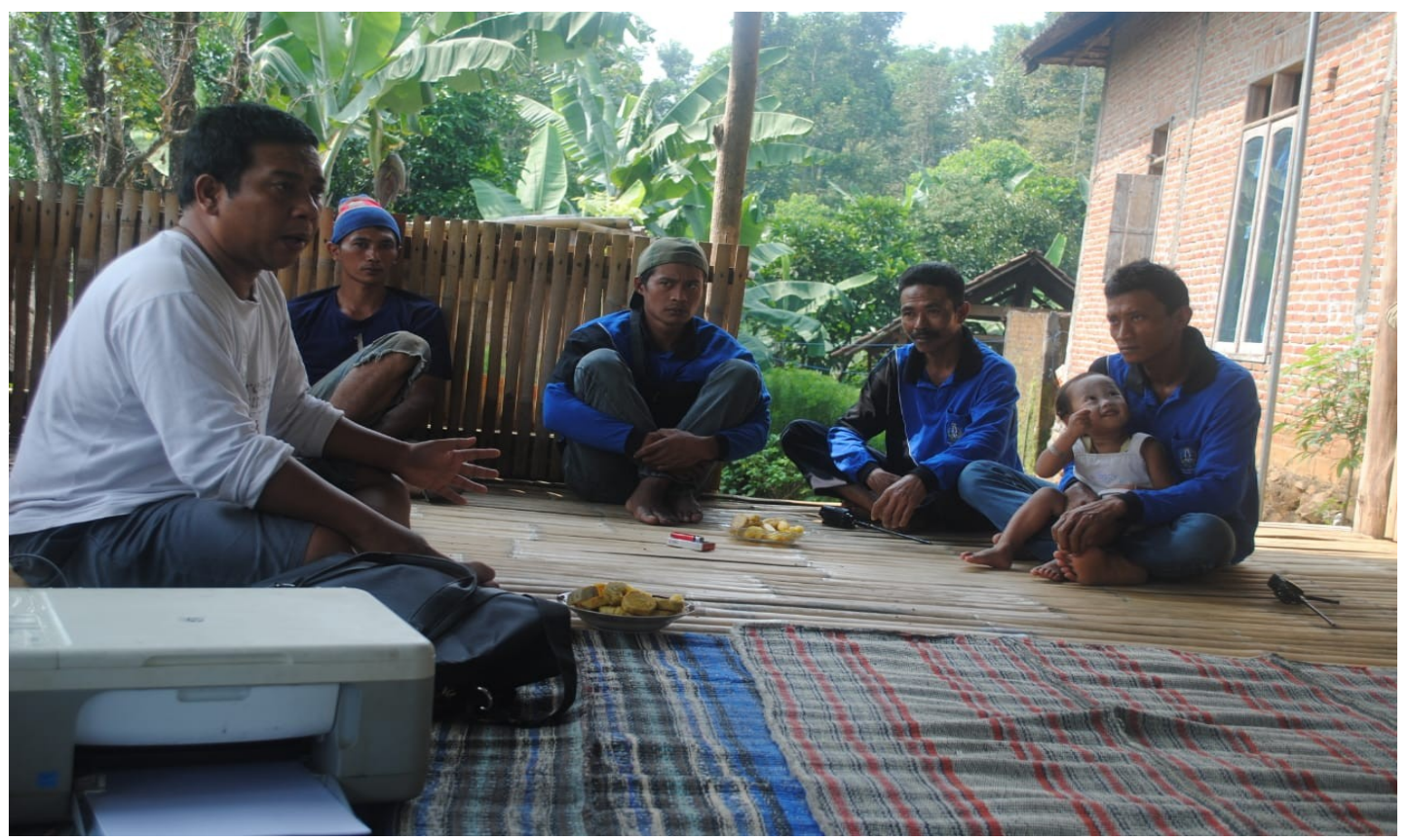

Gambar 2 Penyuluhan di Tourist Information Center

\section{SIMPULAN DAN SARAN}

\section{Kesimpulan}

Kesimpulan yang dapat diuraikan dari pelaksanaan kegiatan pengabdian ini sebagai berikut.

(a) Semua warga yang menjadi peserta pelatihan antusias dan memiliki komitmen yang baik untuk mengikuti semua program pengabdian masyarakat yang diselenggarakan tim pelaksana.

(b) Telah ada peningkatan pemahaman dan keterampilan masyarakat dalam pengelolaan pariwisata berbasis masyarakat dengan produk utama ekowisata. Hal tersebut tervalidasi melalui dinamika di lapangan yang dipantau oleh Kepala Desa, di mana terbukti ada gerakan yang positif di masyarakat untuk bersungguh-sungguh memajukan desa tempat tinggal menjadi desa ekowisata.

(c) Terjadi peningkatan kualitas wisatawan ekowisata, khususnya dari kalangan tamu mancanegara yang memiliki kepedulian serta minat khusus dalam hal ekowisata.

\section{Saran}

Diperlukan keterlibatan pemerintah untuk skala yang lebih massif untuk mempercepat pembangunan destinasi wisata berbasis ekowisata di Dusun Mendiro, Desa Panglungan, Kecamatan Wonosalam. Selama ini, melalui skim PPDM Kementerian Ristek dan Dikti telah berhasil dihimpun dan dikolaborasikan beberapa unsur Pemda Jombang, di antaranya Dinas Lingkungan Hidup, Dinas Pariwisata dan Badan Perencana Pembangunan Kota (Bappeko). Tetapi, dibutuhkan kesinambungan program pembangunan daerah dari Pemkab Jombang.

\section{DAFTAR PUSTAKA}

Kusmayadi. 2004. Statistik Pariwisata Deskriptif. Gramedia Pustaka Utama. Jakarta

Nurhidayati, Sri Endah. 2003. Motivasi dan Pola Konsumsi Wisatawan Dalam Kegiatan Rekreasi di Obyek Agrowisata Kebun Teh Wonosari Lawang, Malang. Laporan Penelitian. Fakultas Ilmu Sosial dan Ilmu Politik. Universitas Airlangga. Surabaya

Nurhidayati, Sri Endah. 2005. Perilous Ekonomi Masyarakat dalam Memanfaatkan Peluang Kerja dan Usaha di Sekitar Obyek Agrowisata Wonosari Lawang. Laporan Penelitian. Fakultas Ilmu Sosial dan Ilmu Politik. Universitas Airlangga. Surabaya

Nurhidayati, Sri Endah. 2008. Community-Based Tourism (CBT) Sebagai Pendekatan Pariwisata Berkelanjutan. http://www.journal.unair.ac.id/filerPDF/com munity $\% 20$ Based $\% 20$ Tourism $\% 20$ CBT_p $\underline{\mathrm{df}}$

Undang-undang Nomer 10 Tahun 2009 tentang Kepariwisataan

Satrya, Dewa Gde. 2008. Manajemen Pariwisata Batu. Jurnal Social \& Humaniora. Lembaga 
Penelitian dan Pengabdian Kepada

Masyarakat Universitas Surabaya

Sentra Wisata Agro Pertanian, Dinas Pariwisata Jawa Timur, 2006

Sentra Wisata Agro Peternakan, Dinas Pariwisata Jawa Timur, 2006

Windia, Wayan, Wirartha, Made, Suamba, Ketut, Sarjana, Made. Model Pengembangan Agrowisata di Bali. Jurnal Sosial Ekonomi. Fakultas Pertanian Universitas Udayana.

Bali.

ejournal.unud.ac.id/abstrak/(13)\%20socawindia\%20dkk-agrowisata(2).pdf -

www.responsibletravel.com

www.jatim.go.id

Yoeti, Oka A. 2008. Ekonomi Pariwisata: Introduksi, Informasi dan Aplikasi. Penerbit Buku Kompas. Jakarta 